\title{
Role of Media in Creating Awareness about Climate Change- A Case Study of Bijapur City
}

\author{
Dr. Onkargouda Kakade, Shilpa Hiremath and Namrata Raut \\ ${ }^{1}$ Associate Professor and Chairperson, Dept. of Journalism and Mass Communication, Karnataka State \\ Women's University, Bijapur- 586108, Karnataka, India. \\ ${ }^{1}$. Executive-Media Relations, Connect Media and community Relations, \#305, $6^{\text {th }}$ Main Road, KHB Colony, \\ Basaveshwar Nagar, Bangalore - 560079, \\ ${ }^{1}$ Research Scholar, Dept. of Journalism and Mass Communication, Karnataka State Women's University, \\ Bijapur-586108, Karnataka, India.
}

\begin{abstract}
Climate change is a long-term change in the statistical distribution of weather patterns over periods ranging from decades to millions of years. The Projected climate change impact scenarios indicate increase in and variable trend of both rainfall and temperature into the $21^{\text {st }}$ century, reduction in the quantity of surface run off across the various river basins, droughts and intensity of floods in various parts of the country. Major environmental issues are through Forest and Agricultural land degradation, Resource depletion (water, mineral, forest, sand, rocks etc.,), Environmental degradation, Public Health, Loss of Bio diversity, Loss of resilience in ecosystems, Livelihood Security for the PoorThe communication of climate change from scientists and policy-makers to the public via the mass media has been a subject of major interest because of its implications for creating national variation in public understanding of a global environmental issue. With all this back ground this research is to assess the role of media in creating awareness about the climate change in Bijapur city. Even it is intended to find which media is best in making the people understand about Climate Change.

Key Words: Causes, Climate change, Impacts, Projections, Role of media
\end{abstract}

\section{Introduction:}

Climate change is a long-term change in the statistical distribution of weather patterns over periods ranging from decades to millions of years. It may be a change in average weather conditions or the distribution of events around that average (e.g., more or fewer extreme weather events). Climate change may be limited to a specific region or may occur across the whole Earth. The rapid growing population and economic development is leading to a number of environmental issues in India because of the uncontrolled growth of urbanization and industrialization, expansion and massive intensification of agriculture, and the destruction of forests.

Major environmental issues are through Forest and Agricultural land degradation, Resource depletion (water, mineral, forest, sand, rocks etc.,), Environmental degradation, Public Health, Loss of Bio diversity ,Loss of resilience in ecosystems, Livelihood Security for the Poor. It is estimated that the India's population will increase to about 1.26 billion by the year 2016. The projected population indicates that India will be the first most populous country in the world and China will be ranking second in the year 2050. India having $18 \%$ of the world's population on $2.4 \%$ of world's total area has greatly increased the pressure on its natural resources (Huma Mustafa Beg; 2008). Water shortages, soil exhaustion and erosion, deforestation, air and water pollution afflicts many areas.

\subsection{Causes of Climate Change}

The causes of climate change can be divided into two categories, human and natural causes. It is now a global concern that the climatic changes occurring today have been speeded up because of man's activities. The natural variability and the climate fluctuations of the climate system have always been part of the Earth's history however there have been changes in concentrations of greenhouse gases in the atmosphere growing at an unprecedented rate and magnitude (Krishan Kalra; 2008). The United Nations, governments and many top scientists around the world believe that we must act now to stabilize and arrest further changes.

To understand climate change fully, the causes of climate change must be first identified. Scientists divide the causes into two categories, natural and human causes. The earth's climate is influenced and changed by natural causes like volcanic eruptions; ocean current, the earth's orbital changes and solar variations. Whereas Agriculture, Deforestation, Shattering some of the Green myths are human causes of climate change. 


\subsection{Impacts of Climate Change}

Climate change has large impacts on the atmosphere, biosphere, sea and water levels, agriculture, temperature, rain, ecosystems, forestry...etc. When it affects the natural systems then directly or indirectly affects the living beings in turn. A large body of scientific studies, exhaustively reviewed, has produced a long list of possibilities.

The following are the likely consequences of warming by a few degrees Celsius - that is, what we may expect if humanity manages to begin restraining its emissions soon, so that greenhouse gases do not rise beyond twice the pre-industrial level. Without strong action the doubling will come well before the end of this century, bringing the planet to temperatures not seen since the spread of agriculture. By 2007, many of the predicted changes were observed to be actually happening (C. Gregory Knight-2009).

Most places will continue to get warmer, especially at night and in winter. The temperature change will benefit some regions while harming others - for example, patterns of tourism will shift. The warmer winters will improve health and agriculture in some areas, but globally, mortality will rise and food supplies will be endangered due to more frequent and extreme summer heat waves and other effects. Regions not directly harmed will suffer indirectly from higher food prices and a press of refugees from afflicted regions.

Sea levels will continue to rise for many centuries. The last time the planet was $3^{\circ} \mathrm{C}$ warmer than now, the sea level was at least 6 meters (20 feet) higher. That submerged coastlines where many millions of people now live, including cities from New York to Shanghai and Mumbai. The rise will probably be so gradual that later generations can simply abandon their parents' homes, but a ruinously swift rise cannot be entirely ruled out (R.K. Kohli-2011). Meanwhile storm surges will cause emergencies. Ecosystems will be stressed, although some managed agricultural and forestry systems will benefit, at least in the early decades of warming. Uncounted valuable species, especially in the Arctic, mountain areas, and tropical seas, must shift their ranges. Many that cannot will face extinction. A variety of pests and tropical diseases are expected to spread to warmed regions. These problems have already been observed in numerous places. Increased carbon dioxide levels will affect biological systems independent of climate change. Some crops will be fertilized, as will some invasive weeds (the balance of benefit vs. harm is uncertain). The oceans will continue to become markedly more acidic, gravely endangering coral reefs, and probably harming fisheries and other marine life.

\subsection{Climate Change and Media}

Because of the severe effect of climate change it is the need of hour to study the reasons, causes and impacts of climate change and it is very urgent to create awareness about causes and impacts of climate change. In these days media has became the important part of life. However, we know that, mass media is to inform and educate the people. Awareness is the key role to reduce these impacts of climate change. Media can play a vital role in creating awareness about climate change. Much research has not been conducted into the representation of climate change in the media. Specifically, the communication of climate change from scientists and policymakers to the public via the mass media has been a subject of major interest because of its implications for creating national variation in public understanding of a global environmental issue.

Media knows the significance of covering environmental issues. All media like T V, Radio, Newspaper and new media spread the news and information at the speed of light. Language press, regional papers, small papers they all give at least minimum importance to climate change coverage. These small papers information helps the people to know the regional climate and weather.

\section{Scope and Significance of the study:}

Climate change is one of the natural happenings which affect human life. Due to globalization we are frequently undergoing climate change. Being aware of climate change, can help us to lead the healthy life. Media is to inform, media can help the people to know climate change and its impacts. Radio, television, newspapers, internet take part in making the people to know about climate change. This study will help to check the credibility of media in creating awareness of climate change. This study will help the media to overcome their short comings and improvise the coverage of climate change issues. This study can help the readers to choose the media to get the more relevant and useful data from the specified sources.

\section{Statement of the problem:}

"Role of media in creating awareness about climate change; a case study of bijapur city". Therefore, it was felt necessary to have an in-depth research study on this topic. Besides, these kinds of studies have not conducted in bijapur. Hence, with this advantage the present investigation carried out with the following objectives. 


\section{Objectives of the Study:}

- To study which media is best to know about the Climate Change.

- To assess the utilization of media content about the Climate Change.

- To indentify whether the media content is relevant or not.

- To examine that the media content about Climate Change is understandable or difficult to understand.

- To understand how media cover climate change issues as well as choices and challenges to employ them.

- To suggest how media cover climate change stories in the context of awareness.

\section{Review of literature:}

The present investigation was designed to study the role of Media in creating awareness about climate change. It was also intended to know what the rate do the people have credibility on Media to assess climate change. Keeping the above aspects in view, the relevant literature has been reviewed and presented below:

Bern, Berlin, Bruxelles, Frankfurt and Main, Oxford, Wien, (2009), Climate Change and the Media brings together an international group of scholars to discuss one of the most important issues in human history: climate change. Since public understanding of the issue relies heavily on media coverage, the media plays a pivotal role in the way we address it. This edited collection - the first scholarly work to examine the relationship between climate change and the media - examines the changing nature of media coverage around the world, from the USA, the UK, and Europe, to China, Australasia, and the developing world.

Nimish Kapoor ,(2011), The present study was to assess the role different information channel among the people of Shringverpur village, Allahbad District. It is found that, approximately $40 \%$ of the people preferred television programmes whereas $26 \%$ of the rural people showed their interest in radio programmes. Hence, information channels can play a important role to bridge the gap between science and society.

Apolinary Tairo,( 2011), studied to know the role of print media in creating awareness about climate change in Tanzania, Africa. It is learnt from the study that Print media, which is still dominant and most influential compared to electronic media (internet, radio, television, blogs, etc.) in Africa, has so far played a leading role in educating and informing the public on effects of environmental deterioration and related human impacts. But little has been done on climate change.

Dr. Y Prabhanjan Yadav, Rapaka Jhansi Rani, (2011), Media plays a vital role in educating and enlightening the people and the governments to protect and preserve natural resources in the interests of future generations and the climatic chaos. Sustainable Development is attained by protecting the environment in a judicious use of natural resources. Countries both the rich and the poor have an equal stake in this stewardship of the earth. The very survival of our planet depends upon it. In this regard media plays a pivotal role in creating awareness and bringing the positive behavioral change among people in mitigating the anthropogenic climate change. Hence, the role of Communication and Mass Media is immense in climate change and sustainable development.

Dr Mike Shanahan, 2011, the media plays very important in educating the people about climate change. It can inform vulnerable impacts and how they can adopt to them, and reduce the amount of earth warming. Media coverage of climate change can give better informed publics, policymakers and more effective policy making. Better media coverage of climate issue can raise the alarm of environmental issues like global warming, acids rain. Across the world media can create the awareness of the challenges that developing nations face, and promote a sustainable outcome to the intergovernmental climate change negotiations.

Dr Adam Corner, Panos eastern Africa, 2011, In Uganda there are many daily newspapers, several local and national TV stations, and hundreds of FM radio stations - some broadcasting to the entire country, others to a single district. Although the local FM radio stations reach by far the largest number of people (many Ugandans are not able to read well, and do not have consistent access to electricity or televisions), the newspapers - especially the Daily Monitor and the New Vision - carry significant influence. It is important, therefore, to understand how climate change is reported across different mediums. There are a number of media development issues in Uganda. Media houses face a level of harassment and government interference, journalists generally have some theoretical training, but most have not had the support to put this training into practice. Radio stations suffer from many of the problems common in the East African region: a very weak financial base and poor journalism capacity. Each of these factors plays a role in the capacity of the media to communicate effectively on critical issues like climate change.

Yuki Sampei, Midori Aoyagi-Usui, 2008, this study was to analyze the Japanese newspaper coverage of global warming from January 1998 to July 2007. Before January 2007, it is found that coverage of global warming had an immediate but short-term influence on public concern. With such transitory high levels of media coverage it is suggested that for more effective communication of climate change, strategies aimed at maintaining mass-media coverage of global warming are required. 
Jessada Salathong, 2009, This study was conducted to know the Newspapers coverage of climate change in Thailand and this study reveals that, Matichon newspaper covers the most about climate change, remaining popular and in remaining newspapers few articles of climate change could be seen.

Dirk von Schneidemesser, 2011, this was ten years 2000-2010 research of increasing frequency of articles relating to climate change in Indian newspapers. Results show that in 2009 there 484 articles were published, it was almost the double of articles published in 2008. In 2007194 articles its almost double than the before years. By this study it can be concluded that frequency of coverage is been increasing by every year.

Amoli Martha Rodrigues, 2008, it was to analyse the study of readers of two daily newspapers in Mangalore city about global warming. Interesting fact is that people of Mangalore know about global warming through the medium of newspapers only. Mangalore people like to read the newspaper Deccan Herald for environmental issue. They find this newspaper is easy to understand environmental issues compared to The Hindu, another leading newspaper in India. Readers even opined that photographic coverage is good and they consider environmental news very effective.

\section{Methodology}

The research design of this study was random sampling method. Its overall objectives are to study the role of media in creating awareness about climate change. In this study, random sampling method is used. Total 135 respondents were selected from Karnataka State Women University, Bijapur.

To study, questionnaire technique was adopted. Questionnaire is meant a set of questions developed in an organized and ordered manner to get the information from the respondents in relation to a given problem. For this, both closed and open ended questionnaire are used. The primary data collected from the sample population through interview schedule is analyzed with the help of statistical tools like percentage, average, ratios and weighted averages to make projections and to draw meaningful conclusions and further substantiated through statistical tests.

\section{Findings and Discussions}

In this chapter the findings of the study are presented and discussed on the basis of analyzing the questionnaire. In this research the researcher has selected 135 samples in order to know the role of media in creating awareness about climate change. The questionnaire has been divided into 2 parts, first part deals with usage of four medias i.e Newspaper, Radio, Television, Internet. Second part is concerned with analyzing the media in assessment of climate change.

Media at Home

\begin{tabular}{|l|l|l|l|}
\hline Sl.no & Medium & Respondents & Percentage \\
\hline 1 & Television & 121 & 89.96 \\
\hline 2 & Newspaper & 114 & 84.44 \\
\hline 3 & Mobile & 114 & 84.44 \\
\hline 4 & Radio & 86 & 63.73 \\
\hline 5 & Magazine & 81 & 60.00 \\
\hline 6 & Internet & 28 & 20.74 \\
\hline
\end{tabular}

A critical examination of table 4.1 indicates that 89.96(121) percent of the respondents have television in their homes, 84.44 (114) percent of the respondents subscribe for newspapers, 84.44(114) Percent of the respondents use mobiles, 63.73(86) percent of the respondents listen to radios, 60.00(81) percent of the respondents have magazine in their homes, and 20.74(28) percent of the respondents browse internet.

The above result clearly shows that the more respondents use television in their homes and comparatively more respondents have less usage of internet in their homes

Reading Newspaper, Watching TV, Listening Radio, and Browsing Internet.

\begin{tabular}{|l|l|l|l|l|l|l|l|l|}
\hline Opinion & Newspaper & \multicolumn{1}{|c|}{ Television } & $\mathbf{\%}$ & Radio & $\mathbf{\%}$ & Internet & \% \\
\hline Daily & 109 & 80.74 & 97 & 71.85 & 56 & 41.48 & 45 & 33.33 \\
\hline $\begin{array}{l}2-3 \text { days } \\
\text { in a week }\end{array}$ & 12 & 8.88 & 11 & 8.14 & 27 & 20.00 & 22 & 16.29 \\
\hline $\begin{array}{l}\text { Once in a } \\
\text { week }\end{array}$ & 4 & 2.96 & 10 & 7.40 & 17 & 12.59 & 32 & 23.70 \\
\hline Rarely & 10 & 7.40 & 17 & 12.59 & 27 & 20.00 & 25 & 18.52 \\
\hline Not at all & 0 & 0 & 0 & 0 & 8 & 5.9 & 11 & 8.15 \\
\hline Total & $\mathbf{1 3 5}$ & $\mathbf{1 0 0}$ & $\mathbf{1 3 5}$ & $\mathbf{1 0 0}$ & $\mathbf{1 3 5}$ & $\mathbf{1 0 0}$ & $\mathbf{1 3 5}$ & $\mathbf{1 0 0}$ \\
\hline
\end{tabular}


The foremost significant outcome of the table 4.2 is 80.74 (109) percent of the respondents read newspaper daily, 71.85(97) percent of the respondents watch television daily, 41.48(56) percent of the respondents listen to radio daily, and 33.33(49) percent of the respondents go through internet daily.

20.00(27) percent of the respondents listen to radio 2-3 days in a week, and 16.29(22) percent of the respondents go through internet 2-3 days in a week, 8.88(12) percent of the respondents read newspaper 2-3 days in a week, 8.14(11) percent of the respondents watch television 2-3 days in a week.

23.70 (32) percent of the respondents go through internet once in a week, 12.59 (17) percent of the respondents listen to radio once in a week, 7.40(10) percent of the respondents watch television once in a week, and 2.96(4) percent of the respondents read newspaper once in a week.

20.00(27) percent of the respondents listen to radio rarely, 18.52(25) percent of the respondents go through internet rarely, 12.59(17) percent of the respondents watch television rarely and 7.40(10) percent of the respondents read newspaper rarely.

$5.9(8)$ percent of the respondents not at all listen to radio, and $8.15(11)$ percent of the respondents not at all go through internet.

The above result clearly shows that the more respondents read newspaper daily, watch television, listen radio and go through internet more then 2-3 days a week or rarely and so on.

Daily time spent on reading Newspaper, Watching television, Listening Radio, Browsing Internet.

\begin{tabular}{|c|c|c|c|c|c|c|c|c|}
\hline Duration & $\begin{array}{l}\text { News } \\
\text { paper }\end{array}$ & $\%$ & TV & $\%$ & Radio & $\%$ & $\begin{array}{l}\text { Interne } \\
t\end{array}$ & $\%$ \\
\hline $\begin{array}{l}\text { Less than } 15 \\
\text { minutes }\end{array}$ & 45 & 33.33 & 12 & 8.89 & 53 & 39.26 & 7 & 5.19 \\
\hline $\begin{array}{l}\text { 15-30 } \\
\text { minutes }\end{array}$ & 55 & 40.74 & 18 & 13.33 & 53 & 39.26 & 14 & 10.37 \\
\hline $\begin{array}{l}30-60 \\
\text { minutes }\end{array}$ & 21 & 15.55 & 28 & 20.74 & 16 & 11.85 & 28 & 20.74 \\
\hline $\begin{array}{l}1 \text { hour to- } \\
\text { 2hours }\end{array}$ & 10 & 7.47 & 49 & 36.29 & 10 & 7.41 & 48 & 35.56 \\
\hline $\begin{array}{l}\text { More than } \\
\text { 2hours }\end{array}$ & 4 & 2.96 & 28 & 20.74 & 3 & 2.22 & 38 & 28.15 \\
\hline Total & 135 & 100 & 135 & 100 & 135 & 100 & 135 & 100 \\
\hline
\end{tabular}

The findings of the table 4 indicates that 39.26(53) percent of the respondents listen to radio, 33.33(45) percent of the respondents read newspaper, 8.89(12) percent of the respondents watch television, and 5.19(7) percent of the respondents go through internet for less than 15 minutes.

40.74(55) percent of the respondents read newspaper, 39.26 (53) percent of the respondents listen to radio, 13.33(18) percent of the respondents watch television, and 10.37 (14) percent of the respondents go through internet for 15-30 minutes.

20.74(28) percent of the respondents watch television, 20.74(28) percent of the respondents go through internet $15.55(21)$ percent of the respondents read newspaper, and 11.85(16) percent of the respondents listen to radio for 30-60 minutes.

36.29(49) percent of the respondents watch television, 35.56(48) percent of the respondents go through internet, 7.47 (10) percent of the respondents read newspaper and 7.41(10) percent of the respondents listen to radio for 1 to 2 hours.

28.15(38) percent of the respondents go through internet, 20.74(28) percent of the respondents watch television, 2.96(4) percent of the respondents read newspaper and 2.22(3) percent of the respondents listen to radio for more than 2 hours.

Source of climate change Information

\begin{tabular}{|l|l|l|l|l|l|l|l|l|l|}
\hline Newspaper & \% & Television & \% & Radio & \% & Internet & \% & Friend & \% \\
\hline 51 & 37.78 & 58 & 42.96 & 15 & 11.11 & 10 & 7.40 & 1 & 0.74 \\
\hline
\end{tabular}

A keen Observation of table 6 says that, 42.96(58) percent of the respondents get to know about Climate Change by watching television, 37.78(51) percent of the respondents get to know by reading newspaper, 11.11(15) percent of the respondents come to know from Radio, 7.40(10) percent of the respondents come to know by browsing internet and merely $0.74(1)$ of the respondents come to know about the climate change by friends. 
Role Of Media In Creating Awareness About Climate Change- A Case Study Of Bijapur City

Climate change information from media

\begin{tabular}{|c|l|l|l|l|l|l|l|l|}
\hline \multirow{2}{*}{ newspaper } & Article & Percent & News & $\%$ & Editorial & $\%$ & Advertisements & $\%$ \\
\cline { 2 - 10 } & 17 & 33.33 & 25 & 49.02 & 8 & 15.67 & 1 & 1.96 \\
\hline \multirow{3}{*}{ Radio } & Talk/Featur & Percent & News & Percent & Drama & Percent & Advertisements & Percent \\
\cline { 2 - 10 } & 5 & 33.33 & 8 & 53.33 & 2 & 13.33 & 0 & 0 \\
\hline \multirow{2}{*}{ Television } & Program & $\%$ & News & $\%$ & Document & $\%$ & Advertisements & $\%$ \\
\cline { 2 - 10 } & 21 & 36.20 & 32 & 55.17 & 2 & 3.44 & 3 & 5.17 \\
\hline \multirow{2}{*}{ Internet } & Article & $\%$ & News & $\%$ & Networks & $\%$ & Advertisements & $\%$ \\
\cline { 2 - 9 } & 2 & 20 & 2 & 20 & 3 & 30 & 3 & 30 \\
\hline
\end{tabular}

The above Table says that $49.02(25)$ percent of the respondents come to identify about the climate change by reading news columns, where as $53.33 \%$ respondents come to known about climate change through radio news. This table even exhibits 55.17(32) percent of the respondents come to know about climate change by watching news in television. And amongst them 30 percent of the respondents come to know about climate change by seeing social network discussion and advertisements Here the above table results that more respondents gaze at news to know about climate change.

Analysis of media content regarding the climate change

\begin{tabular}{|c|c|c|c|c|c|c|}
\hline \multirow[t]{2}{*}{ Relevance } & Relevant & Percent & $\begin{array}{l}\text { Most } \\
\text { Relevant }\end{array}$ & Percent & $\begin{array}{l}\text { Not } \\
\text { Relevant }\end{array}$ & percent \\
\hline & 81 & 60 & 48 & 35.56 & 6 & 4.44 \\
\hline \multirow[t]{2}{*}{ Reliability } & $\begin{array}{l}\text { Full } \\
\text { reliable }\end{array}$ & $\%$ & $\begin{array}{l}\text { Some } \\
\text { Extent }\end{array}$ & $\%$ & Not at all & $\%$ \\
\hline & 47 & 34.81 & 82 & 60.74 & 6 & 4.44 \\
\hline \multirow{2}{*}{$\begin{array}{c}\text { Level of } \\
\text { understanding }\end{array}$} & Very easy & $\%$ & Easy & $\%$ & Not Easy & $\%$ \\
\hline & 55 & 40.74 & 75 & 55.56 & 5 & 3.70 \\
\hline \multirow{2}{*}{$\begin{array}{l}\text { Extent of } \\
\text { Utilization }\end{array}$} & Fully & $\%$ & $\begin{array}{l}\text { Some } \\
\text { extent }\end{array}$ & $\%$ & Not at all & $\%$ \\
\hline & 38 & 36.19 & 67 & 63.81 & - & - \\
\hline
\end{tabular}

Table 7 shows that majority of the respondents consent that 60(81) percent say that the content regarding the climate change is relevant, 35.55(48) percent say it is most relevant and only 4.44(6) percent say the content is not at all relevant. We can see that, 34.81(47) percent of respondent say that media information of climate change is full reliable and only 4.44(6) respondents say that the media content about the climate change is not at all reliable.

It is evident that, more than half of the respondents 55.56(75) percent of the respondents declare that the media content regarding climate change is easy to understand, 40.74(55) percent declare that it is very easy and only 3.70 (5) respondents say that the media content about the climate change is not easy to understand. The above table says that 63.81(67) percent of the respondents use media content regarding Climate Change in their lives for some extent, similarly 36.19(38) percent of the respondents uses this media content to full extent, amongst 77.78(105) percent.

\section{Conclusion}

In a democratic country like India, media is a fourth pillar of the democracy due to its social responsibilities. Media of India consist of several different types of communications media: television, radio, cinema, newspapers, magazines, and Internet-based Web sites. Many researchers have now been conducted into the representation of climate change in the media. Specifically, the communication of climate change from scientists and policy-makers to the public via the mass media has been a subject of major interest because of its implications for creating national variation in public understanding of a global environmental issue. However, to date, no study has assessed the situation in India.

The role of mass media in shaping public understanding of environmental issues has been well documented in recent years (Burgess 1990). Much research has theorized on and now established the role of the mass media in 'framing' and re-forming climate change issues, whether scientific or political.

This study clearly states that majority of the respondents (89.96 per cent) have television in their homes.It is evident from the study that ( 80.74 per cent) of the respondents daily read newspaper and (71.85 per cent) of the respondents watch television daily.A close observation of the study shows that there are (21.48per cent) of the respondents read Deccan Herald and the same respondents (21.48 per cent) read Vijaya Karnataka as well.The majority of the respondents spend their time for particular media in a day is, newspaper (15-30min), 
television (1- 2 hours), radio (15-30min) and internet (1-2hours). Nearly half of the total respondents (43.70percent) say that internet is the following media as major source of information. All the respondents of the study know about the climate change. A large percentage of respondents (42.96per cent) know about the climate change through television. A great majority of respondents (49.02percent) come to know about the climate change by news columns in newspapers, (53.33percent) know through news in radio, (55.17percent) of the TV watchers come to know through news, and (30percent) of the respondents know through social network discussion and advertisements in internet.

A large percentage of respondents (60percent) say that the media content regarding the climate change is relevant and (86.67percent) of the respondents says that they get complete information regarding climate change through media and (77.78percent) utilize media content in their life and amongst them (63.81 percent) use that for some extent. Thus, in Bijapur Television is the most popular media among people to know about climate change, followed by Newspaper, Radio and Internet respectively.

\section{References:}

[1]. Anjum Nasreen Rizvi \& P.T. Bhutia; 2008,"Nematodes as Bioindicators of Climate Change; United Nations Educational, Scientific \& Cultural Organization".

[2]. A.N. Shukla; 2008, " Shisham Mortality and its correlation with climate change; United Nations Educational, Scientific \& Cultural Organization".

[3]. Arshinder Kaur; 2008, "Mitigation Climate Change: Policy Issues for prompting organic farming; United Nations Educational, Scientific \& Cultural Organization".

[4]. BACC Author Team, 2008, "Assessment of Climate Change for the Baltic Sea Basin."

[5]. Bala Prasad; 2008, "Policy for sustainable forest development for increasing carbon sink and migiting climate change; United Nations Educational, Scientific \& Cultural Organization”.

[6]. Committee to Review the U.S. Climate Change Science, Climate Research Committee, National Research Council; 2005; "U.S. Climate Change Science Program's Synthesis and Assessment Product on Temperature Trends in the Lower Atmosphere; U.S"

[7]. C. Gregory Knight, Pennsylvania State University, Jill Jager, Vienna; October 2009; "Integrated Regional Assessment of Global Climate Change".

[8]. Human Mustafa Beg; 2008, “Climate Change and Developing Nations; United Nations Educational, Scientific \& Cultural Organization".

[9]. Jochem Eberhard; Sathaye Jayant A Bouille, Daniel; 2001; "Society Behaviour and Climate Change Mitigation".

[10]. Krishan Kalra; 2008, "Climate Change, biodiversity and Food Security in the South Asian Region. United Nations Educational, Scientific \& Cultural Organization”.

[11]. K. Venkataraman; 2008, “Climate change and biodiversity in Indian; United Nations Educational, Scientific \& Cultural Organization".

[12]. M. A. Ali Khan and M. Iftikhar Ali; 2008, “ Climate change due to global warming and its impacts on plants and bird migration in Indian subcontinent; United Nations Educational, Scientific \& Cultural Organization”.

[13]. M. Al-Amin and M. R. Ullah, 2008, “ Impacts of climate change on tree species diversity of hill forests of Bangladesh; United Nations Educational, Scientific \& Cultural Organization”.

[14]. Namarta Gupta, R.C. Sharma, G.S. Mahal and Navdeep Jindal, 2008, "Seed storage for food security; United Nations Educational, Scientific \& Cultural Organization".

[15]. Neil T. Gavin, Liam Leonard-Milsom, Jessica Montgomery; May 2011, "Climate change, flooding and the media in Britain."

[16]. New York, Bern Berlin, Bruxelles, Frankfurt am Main, Oxford Wien; 2009; "Climate Change and the Media."

[17]. Onkar Singh Brraich and Satnam Singh Ladhar, 2008, “ Impact of climate change on fish production in India; United Nations Educational, Scientific \& Cultural Organization”.

[18]. P.R.Shukla, Subodh K.Sharma, Amit Gard \& Suman Bhattacharya; 2003; "Climate Change and India - Vulnerability Assessment and Adaptation."

[19]. P.S. Roy 2008, “Human Dimensions Climate Change; United Nations Educational, Scientific \& Cultural Organization”.

[20]. P. S. Roy \& Arijit Roy, 2008, "Impact of climate change on biodiversity: The human dimensions; United Nations Educational, Scientific \& Cultural Organization”.

[21]. Ram Boojh; 2010, "Addressing climate change and bio diversity issues in the south Asian region; United Nations Educational, Scientific \& Cultural Organization”.

[22]. Ram Boojh, Sara Nowroozalizadeh \& Jihane Giraud, 2008, “ The impact of climate change and the Himalayas in the local context: The case of nanda devi biosphere reserve; United Nations Educational, Scientific \& Cultural Organization".

[23]. R.K. Kohli, Daizy Batish and H.P. Singh, 2011, "Ecological Threats from Alien Invasive Plants in Himachal Pradesh, India; United Nations Educational, Scientific \& Cultural Organization”.

[24]. Stephen Peake and Joe Smith; 2009; "Climate Change."

[25]. Sarita Sharma, Sanjeev Sharma and A.K. Nath, 2008, “ transgenic crops- effect on biodiversity; United Nations Educational, Scientific \& Cultural Organization".

[26]. S. P. Sharma, 2008, "An Assessment of Alternative Scenarios of climate change and its impact and opportunities in food security; United Nations Educational, Scientific \& Cultural Organization”.

[27]. Suman Sahai, 2008, "Agro-biodiversity, climate change and food security; United Nations Educational, Scientific \& Cultural Organization".

[28]. Vergara Walter, Deeb Alejandro, Leino Irene, Kitoh Akio, Kitoh Akio, Escobar Marisa; March 2011; “Assessment of the Impacts of Climate Change on Mountain Hydrology."

[29]. Yogesh Gokhale, G. R. Gargya and Lokendra Singh, 2008, “ Banking on Traditional crop varieties for tackling concerns of food security due to climate variability; United Nations Educational, Scientific \& Cultural Organization". 